\title{
(4) \\ ANALISIS PERSENTASE RESIDU PENCUCIAN FILTER AIR BERSIH PDAM TIRTA MUSI PALEMBANG DENGAN VARIASI WAKTU DAN KONSENTRASI NATRIUM HIDROKSIDA $(\mathrm{NaOH})$
}

\author{
${ }^{1}$ Kiagus Ahmad Roni*, ${ }^{2}$ Evita Sari, ${ }^{3}$ Elvidia, ${ }^{4}$ Netty Herawati \\ ${ }^{1234}$ Program Studi Teknik Kimia, Universitas Muhammadiyah Palembang \\ 1)email : kiagusaroni@gmail.com
}

\begin{abstract}
Abstrak
Sebagian besar instalasi pengolahan Air (IPA) di provinsi Sumatera Selatan menggunakan air Sungai sebagai air baku. Salah satu IPA yang menggunakan air sungai sebagai air baku yaitu IPA Tirta Musi unit Rambutan yang berada di wilayah kerja PDAM Palembang. IPA unit Rambutan memiliki kapasitas produksi $850 \mathrm{~L} / \mathrm{det}$ dengan jumlah pelanggan aktif sebanyak 36.967 pelanggan. permasalahan yang terdapat pada IPA unit Rambutan adalah tingginya headloss (level air) pada filter dan lambatnya waktu pengolahan air. Sehingga kapasitas hasil air pengolahan tidak maksimal (tidak efisien) dan membutuhkan waktu yang lama. Efisiensi pengolahan yang masih rendah mengidentifikasi bahwa pengolahan air yang terdapat pada IPA unit Rambutan kualitasnya menurun. Penelitian ini bertujuan menganalisa berapa konsentrasi dan waktu pencucian media filter yang optimal dengan menggunakan pelarut Natrium Hidroksida $(\mathrm{NaOH})$ dari variasi konsentrasi $2 \mathrm{M}, 4 \mathrm{M}$, $6 \mathrm{M}, 8 \mathrm{M}$ dan $10 \mathrm{M}$ dan variasi waktu selama 15 menit, 20 menit, 25 menit dan 30 menit untuk mengaktivasi media filter sehingga meningkatkan efisiensi filter dan menghasilkan kualitas air yang sesuai dengan peraturan Permenkes No. 492/2010. Hasil penelitian menunjukkan bahwa konsentrasi yang optimal untuk meng-aktivasi media filter (pasir Kuarsa) yaitu 8 M dengan waktu reaksi selama 20 menit. Pengolahan menggunakan pasir kuarsa yang telah di aktivasi mampu menurunkan nilai kekeruhan air dari 4,23 NTU ke 1,10 NTU dan menaikan nilai pH dari 5,95 ke 6,14 serta mampu mempercepat waktu pengolahan dari 13,72 menit menjadi 2,30 menit. Hal ini menunjukkan pencucian media filter menggunakan Chemical sangat berpengaruh terhadap hasil pengolahan air Bersih.
\end{abstract}

Kata Kunci : Filter, Pasir Kuarsa, Saringan Pasir Cepat, $\mathrm{NaOH}$

\section{PENDAHULUAN}

Air merupakan kebutuhan yang paling mendasar bagi makhluk hidup. Adanya perkembangan industri dan pemukiman dapat mengancam kualitas air bersih, sehingga diperlukan upaya perbaikan baik secara sederhana maupun modern. Salah satu proses pengolahan air secara fisik adalah dengan filtrasi, dimana terjadi pemisahan antara padatan / koloid dengan cairan. Pada proses ini, digunakan media filtrasi yang sangat beragam untuk mendukung kelancaran proses pengolahan air bersih. Salah satu media filtrasi yang cukup efektif adalah pasir kuarsa. Sebagian besar instalasi pengolahan Air 
(IPA) di provinsi Sumatera Selatan menggunakan air Sungai sebagai air baku. Salah satu IPA yang menggunakan air sungai sebagai air baku IPAM Tirta Musi unit Rambutan yang berada di wilayah kerja PDAM Palembang. IPA unit Rambutan memiliki kapasitas produksi $850 \mathrm{~L} / \mathrm{det}$ dengan jumlah pelanggan aktif sebanyak 36.967 pelanggan. Penelitian ini bertujuan untuk: a) Meningkatkan efisiensi pasir kuarsa dengan melakukan aktivasi menggunakan pelarut Natrium Hidroksida ( $\mathrm{NaOH})$. b) Menentukan konsentrasi Natrium Hidroksida $(\mathrm{NaOH})$ yang optimum pada proses aktivasi pasir kuarsa. c) Menghasilkan Air bersih yang sesuai dengan peraturan Permenkes No. 492/2010.

\section{TINJAUAN PUSTAKA}

\section{Pengolahan Air}

Tahapan proses pengolahan air yang terjadi di PDAM Tirta Musi Palembang yakni sebagai berikut :

Proses Pendahuluan

Yaitu proses lengkap penghilangan benda kasar dari air yang akan di proses. Umumnya penghilangan dengan cara penyaringan kasar atau screening.

\section{Proses Koagulasi}

Disebut juga pengadukan cepat atau flash mixing setelah bahan kimia (Alumunium sulfat $\left.\left(\mathrm{Al}_{2}\left(\mathrm{SO}_{4}\right)_{2}\right)\right)$ yang dicampur kedalam air sehingga diharapkan pencampuran bahan kimia tersebut (Koagulan) dapat terjadi dengan cepat dan merata. Proses penggumpalan partikel koloid dan pengendapannya disebut Koagulasi. Dalam hal ini, koagulasi secara bersama membentuk zat dengan massa yang labih besar.

\section{Proses Flokulasi}

Proses flokulasi sangat berhubungan erat dengan proses koagulasi, keduanya berhubungan karena adanya destabilisasi tumbukan antar partikel, sehingga terjadi pengikatan satu sama lain sehingga menjadi flok yang lebih besar.

\section{Proses Sedimentasi / Pengendapan}

Diartikan sebagai pengendapan karena diakibatkan oleh gara gravitasi, partiket yang mempunyai berat jenis besar dari pada air akan mengendap kebawah dan yang kecil dari air akan mengapung / melayang. Setelah proses sedimentasi air mengalir ke bak Aerasi, yaitu suatu system oksigenasi melalui penangkapan $\mathrm{O}_{2}$ dari udara pada air olahan yang akan diproses (Perpamsi, 2003).

\section{Filtrasi}

\section{Pengertian Filtrasi}

Filtrasi adalah operasi dimana campuran yang heterogen antara fluida dan partikel-partikel padatan dipisahkan oleh media filter yang meloloskan fluida tetapi menahan partikel-partikel padatan. Hal yang paling utama dalam filtrasi adalah mengalirkan fluida melalui media berpori. Filtrasi dapat terjadi karena adanya gaya dorong, misalnya; gravitasi, tekanan dan gaya sentrifugal (Jhonson, 2007).

\section{Jenis - Jenis Filter}

\section{Saringan pasir cepat (Rapid Sand Filter)}

Sistem ini sering digunakan pada pengolahan air minum. Kecepatan penyaringan pada sistem ini relatif lebih besar dan pencucian penyaringan menggunakan sistem balik (back Washing)

Kriteria saringan pasir cepat adalah :

a. Rata - rata hasil penyaringan 75 sampai 200 / sq. $\mathrm{m} / \mathrm{min}$

b. Banyak kebutuhan filter $(\mathrm{N})=\mathrm{Q}^{(1 / 2)} / 4.69$,

dimana $\mathrm{Q}=$ Kapasitas Inlet $\left(\mathrm{m}^{3} / \mathrm{jam}\right)$

c. Maksimal kedalaman pasir $=\mathrm{Qd}^{\wedge} 3 \mathrm{~h} / 29323 \mathrm{~B}$, dimana $Q=$ Kapasitas Inlet $\left(\mathrm{m}^{3} /\right.$ jam per area $\left.\mathrm{m}^{2}\right), d=$ ukuran pasir $(\mathrm{mm})$, 


\author{
$\mathrm{B}=$ Konstanta $\left(0.4 \times 10^{3}-0.6 \times 10^{-3}\right)$ \\ d. Kedalaman Pasir batu (Gravel) $=30$ sampai $60 \mathrm{~cm}$ \\ e. Ukuran Pasir 0.45 sampai $1 \mathrm{~mm}$ \\ f. Kedalaman air di atas pasir 1 sampai $2 \mathrm{~m}$ (Qasemy, 2015).

\section{Saringan pasir lambat (Slow sand Filter)}

Adalah suatu proses penyaringan dimana air dilewatkan melalui poros dengan kecepatan relatif rendah. Saringan ini memerlukan lahan yang lebih luas. Saringan ini digunakan hanya untuk kekeruhan (turbidity) air < 30 NTU. Pencucian filter ini dengan cara mengeruk pasir 2-3 cm kemudian dikeluarkan dari bak dan di cuci hingga bersih untuk dapat di kembalikan ketempat semula (Quddus, 2014).

\title{
Struktur dan bagian filter
}

\section{a. Struktur Filter Cepat}

Filter cepat dilengkapi dengan alat / perlengkapan yang memungkinkan pencucian media filter didalam bak filter dengn air dan udara secara bersama atau terpisah.Ketebalan filter yang biasanya 1 - $3 \mathrm{~m}$ dan akan semakin tinggi dengan ukuran partikel yang semakin besar.

b. Bak Filter

Adalah bagian yang terisi oleh media filter dan mempunyai bagian pembagi rata air baku maupun media pencuci.

\section{c. Struktur media Filter}

Struktur media filter tesusun dari :

1. Pasir Silikam jenis batuan tinggi

2. Antrasit, yaitu batubara yang memiliki daya evaporasi rendah dan diletakkan pada bagian atas dalam filter.

3. Karbon Aktif, adalah material yang berbentuk bubuk yang berasala dari material yang mengandung carbon misalnya kulit kelapa.

\section{d. Lantai Penyaring}

Lantai Dasar Penyaring berfungsi menahan media penyangga dan media filter, juga untuk membagi drainase air secara merata untuk membagi rata media pencuci (air dan udara).

\section{e. Lapisan Penahan Penyangga}

Lapisan penyangga digunakan untuk menghindari adanya media penyaring terbawa keluar filter dan juga untuk membagi rata air pencucian.

\section{f. Saluran Inlet}

Saluran inlet meliputi semua system pipa dan pelimpa yang dilewati air yang akan disaring didalam unit filter.

\section{g. Saluran Pelimpah}

Saluran pelimpah digunakan untuk membagi rata air baku kedalam filter dan juga untuk membuang air pencucian, saluran pelimpah dalam filter terbuka sering kali didisain sebagai pipa horizontal yang lurus.

\section{h. Katup Udara}

Katup udara pada filter tertutup berguna untuk menghindari adanya lapisan udara didalam filter tertutup. Umumnya digunakanalat pelampung dengan katup atau katup udara yang terbuka secara permanen.

\section{i. Katup Pengatur Aliran}

Katup pengatur aliran harus bias untuk mengatur aliran pada semua unit filtrasi dan untuk membagi kesemua unit secara konstan. 


\section{j. Sistem Pencucian}

Pencucian adalah langkah yang penting untuk menyertai proses penyaringan dan tidak sempurnanya proses pencuciandapat berpengaruh terhadap proses penyaringan secara keseluruhan.

\section{k. Saluran pembuangan}

Pengurasan dilakukan untuk menjamin semua air keluar dari bak filter selama proses pemeliharaan dan perbaikan.

\section{Operasional Filter}

\section{Proses Penyaringan}

Proses penyaringan dilakuakan terhadap air hasil sedimentasi, dimana berfungsi untuk menghilangkan / memisahkan flok (halus) yang tidak terendapkan / lolos dari unit sedimentasi.

\section{Proses Pencucian Filter}

\section{a. Perputaran Pencucian Balik}

Pencucian adalah langkah penting, selama penyaringan ruang - ruang antar butiran pasir diisi flok- flok yang tersaring dan semakin lama akan semakain mengeras. Pencucian dilakukan bila ada salah satu atau gabungan dari tanda - tanda berikut:

1. Kehilangan tekanan mencapai batas maksimal yang dibolehkan

2. Terjadinya terobosan ditandai dengan meningkatnya kekeruhan air hasil penyaringan

3. Satu periode penyaringan biasany amembutuhkan waktu 30-50 jam.

\section{b. Proses Pencucian}

Program pencucian meliputi langkah-langkah proses pencucian filter termasuk media yang digunakan untuk mencuci media filter yaitu air, udara, kombinasi udara dan air, kecepatan pencucian dan putaran waktu (frekuwensi) pencucian media filter serta maupun berupa lama waktu yang digunakan untuk masing- masing langkah, biasanya proses pencucian penyaringan dilakukan dengan berlawanan arah dengan aliran arah proses operasional filter oleh karena itu dikenal dengan sebutan back washing (pencucian balik) (Sutrisno, 1991).

\section{Pasir Kuarsa}

Pasir kuarsa mempunyai komposisi gabungan dari $\mathrm{SiO}_{2}, \mathrm{Fe}_{2} \mathrm{O}_{3}, \mathrm{Al}_{2} \mathrm{O}_{3}, \mathrm{TiO}_{2}, \mathrm{CaO}, \mathrm{MgO}$, dan $\mathrm{K}_{2} \mathrm{O}$, berwama putih bening atau wama lain bergantung pada senyawa pengotornya, kekerasan 7 (skala Mohs), berat jenis 2,65 titik lebur $1715^{\circ} \mathrm{C}$, bentuk kristal hexagonal, panas sfesifik 0,185 dan konduktivitas panas $12-100^{\circ} \mathrm{C}$ (Asmuni, 2008).

\section{Karakteristik Pasir Kuarsa}

Kuarsa adalah mineral utama dari silika dan salah satu mineral pembentuk kristal optik. Struktur atomik dari kuarsa adalah tetra hidron yang satu atom silikon dikelilingi empat atom oksigen. Contoh penting adalah forstart $\left(\mathrm{Mg}_{2} \mathrm{SiO}_{2}\right)$ dalam $\mathrm{MgSiO}_{4}$ ion $\mathrm{SiO}_{4}$ diperoleh empat elektron dari atom magnesium memberikan isatu elektron ke satuan dari $\mathrm{SiO}_{4}$. Pada temperatur kamar, satuan tetra hiral dari silika tersusun dalam suatu susunan heksagonal, tetapi pada temperatur $875^{\circ} \mathrm{C}$ kestabilan susunan tertra hidral silika berubah (Hadi, 2011).

\section{Pasir Batu (Gravel)}

Gravel atau pasir batu adalah bebatuan kecil yang berasal dari batu granit yang dipecahkan. Berukuran antara $2 \mathrm{~mm}$ dan $75 \mathrm{~mm}$ dan sering digunakan dalam pembangunan badan jalan, dan sebagai batu campuran untuk memproduksi bata.

\section{Lumpur (Sludge) Specific gravity (Sg)}


Sg merupakan rasio antara densitas (berat jenis, BJ) lumpur dengan BJ air. Lumpur hampir selalu membentuk flok. Mengetahui densitas flok merupakan hal yang sangat diperlukan pada tiap tahapan pengolahan karena semakin besar densitas maka flok akan semakin mudah mengendap.

\section{Konsentrasi padatan}

Tujuan utama pengolahan lumpur adalah menyisihkan padatan dari air. Berikut ini adalah tabel mengenai konsentrasi padatan yang terkandung di dalam berbagai jenis lumpur (Sugiharto, 1987).

\section{Keterendapan lumpur}

Keterendapan (settleability) lumpur dapat diuji dengan dua macam cara yaitu dengan pengukuran kecepatan zona pengendapan dan sludge volume index.

\section{Ukuran dan bentuk flok / partikel}

Flok dapat berbentuk bulat, lonjong, atau pipih. Ukuran flok dipengaruhi oleh faktor berikut ini:

- Jenis mikroorganisme

- Agitasi (pencampuran/pengadukan)

- Konsentrasi oksigen terlarut

- Umur lumpur

- Karakteristik substrat

\section{Konduktivitas termal}

Konduktivitas termal lumpur akan menurun bersamaan dengan konsentrasi padatan hingga konsentrasi padatan mencapai nilai tertentu (2\% untuk waste activated sludge dan $10 \%$ untuk digested primary sludge). Setelah padatan mencapai nilai tersebut, konduktivitas termal lumpur akan konstan pada kisaran $0.85 \times 10^{-3} \mathrm{cal} \mathrm{cm}^{-1} \mathrm{~s}^{\circ} \mathrm{C}$.

\section{Natrium Hidroksida ( $\mathrm{NaOH})$}

atau biasa disebut dengan istilah soda api atau caustic soda adalah senyawa bersifat basa anorganik (inorganic base compound). $\mathrm{NaOH}$ atau caustic soda digunakan secara luas di sektor industri dan rumah tangga. Pada industri, $\mathrm{NaOH}$ digunakan sebagai bahan kimia basa untuk kebutuhan pembuatan bubur kertas dan kertas, tekstil, air minum, proses pembuatan air aquadest dan aquabidest, sabun, deterjen, industri pembuatan kaca, industri metalurgi dan pengolahan hasil tambang mineral logam, industri percetakan, industri pengolahan rumput laut, dan sebagainya (Windusari, 2015).

\section{Sifat - Sifat}

\section{Sifat-Sifat Fisika}

$\mathrm{NaOH}$ murni memiliki warna putih jernih, yang umumnya diproduksi dalam bentuk flake. Flake $\mathrm{NaOH}$ sangat mudah larut dan memiliki kelarutan yang tinggi dalam air, namun memiliki kelarutan yang lebih rendah dalam ethanol atau methanol (Effendi, 2003).

\section{Sifat-Sifat Kimia Dan Pemakaian NaoH}

$\mathrm{NaOH}$ adalah senyawa basa yang terbentuk dari proses elektrolisa cairan garam $\mathrm{NaCl}$. Pada proses elektrolisa, ion klor dari senyawa $\mathrm{NaCl}$ yang larut dalam air teroksidasi menjadi gas $\mathrm{Cl}_{2}$ pada kutub anoda, kation $\mathrm{H}^{+}$dari air tereduksi menjadi gas $\mathrm{H}_{2}$ di kutub katoda, sehingga kation $\mathrm{Na}^{+}$membentuk pasangan dengan anion $\mathrm{OH}^{-}$dari air, membentuk senyawa $\mathrm{NaOH}$ di wadah elektrolisa (Buchan, 2003). Natrium hidroksida bereaksi dengan larutan asam membentuk air dan garam natrium. Reaksi $\mathrm{NaOH}$ dengan larutan asam $\mathrm{HCl}$ berlawanan dengan reaksi elektrolisa $\mathrm{NaCl}$, dimana reaksi $\mathrm{NaOH}$ dan $\mathrm{HCl}$ justru menghasilkan larutan garam dapur $\mathrm{NaCl}$ (Sunarno, 2002).

Aluminium beraksi dengan soda api dalam waktu yang sangat cepat. Reaksi ini panas awal kepada sistem. Reaksinya sebagai berikut :

$$
2 \mathrm{Al}+2 \mathrm{NaOH}+6 \mathrm{H}_{2} \mathrm{O} \rightarrow 2 \mathrm{NaAl}(\mathrm{OH})_{4}+3 \mathrm{H}_{2}
$$

Reaksi soda api dengan silika (kaca $\mathrm{SiO}_{2}$ ) berlangsung lambat pada suhu rendah. 
Hampir semua senyawa hidroksida logam tak larut, atau hanya larut sebagian dalam air, sehingga tidak efektif jika digunakan sebagai pengendap beberapa ion logam dari larutannya. Karena $\mathrm{NaOH}$ larut sempurna dalam air, maka senyawa kimia ini banyak digunakan sebagai pengendap (precipitant) dalam berbagai reaksi kimia, baik reaksi skala laboratorium, maupun untuk kegunaan industri (Sastrawijaya, 2000).

\section{Produksi}

Anion klor teroksidasi menjadi gas klor yang lepas dari reaktor, dan selanjutnya gas ini di sintesa menjadi larutan $\mathrm{HCl}$. Sedangkan kation $\mathrm{Na}+$ tetap di media reaktor, berikatan dengan ion $\mathrm{OH}-$ yang berasal dari air, membentuk larutan atau kristal $\mathrm{NaOH}$ (EPA, 1990).

\section{METODE PENELITIAN}

\section{Pengambilan Sampel}

Pasir kuarsa dalam bak filter diambil pada bagian tengah sebanyak 1000 gram, kemudian diletakkan dalam Beaker Glass.

\section{Analisa residu Pasir Kuarsa}

Pasir Kuarsa yang diambil dari bak filter lalu di masukan kedalam Gelas Beker diaktivasi menggunakan $1000 \mathrm{~mL}$ air bersih kemudian diolah menggunakan HCL (asam Klorida) $2 \mathrm{M}$ sebanyak $1000 \mathrm{~mL}$ selama 5 - 10 menit. Saring dan bilas menggunakan air, pasir yang telah diolah menggunakan Asam Klorida dikeringkan menggukan Oven dengan Suhu $105-110{ }^{\circ} \mathrm{C}$ selama 1 jam dan masukan ke dalam Desikator selama 10 menit. Ambil sampel yang telah dikeringkan sebanyak masing - masing 10 gram kemudian homogenkan dengan larutan $\mathrm{NaOH} 2 \mathrm{M}, 4 \mathrm{M}, 6 \mathrm{M}, 8 \mathrm{M}$ dan $10 \mathrm{M}$ sebanyak $10 \mathrm{~mL}$ dengan masing - masing waktu 15 menit, 20 Menit, 25 menit dan 30 menit (lakukan $2-3$ kali pengujian). Setelah itu saring dan bilas pasir menggunakan air sebanyak 3x. Kertas saring dan residu di keringkan menggunakan oven dengan suhu $105^{\circ} \mathrm{C}$ selama 1 jam kemudian di masukkan kedalam Desikator selama 10 menit. Timbang berat residu dan hitung persentase residu yang terkandung dalam pasir Kuarsa. Lakukan di tiap variasi konsentrasi Natrium Hidroksida.

\section{Analisa Pengolahan Pasir Kuarsa}

Pasir kuarsa yang digunakan adalah pasir kuarsa yang telah diolah bersih dan pasir kuarsa yang tidak diolah. Pasir kuarsa yang telah diolah dan pasir kuarsa yang tidak diolah di ambil sebanyak 1000 gram lalu dikeringkan pada suhu $105^{\circ} \mathrm{C}$ selama 1 jam dan dimasukan dalam Desikator selama 10 menit. Masing - masing pasir tersebut dimasukan ke dalam tabung Inhop sampai tanda garis $500 \mathrm{~mL}$. Kemudian dimasukkan air hasil proses sedimentasi ( setelah proses aerasi ) kedalam tabung inhop sampai tanda batas $1000 \mathrm{~mL}$ dan lakukan dalam 2x pengulangan. Kemudian diamati kecepatan penyaringan dan warna air setelah penyaringan.

\section{Uji Kualitas Air}

Air hasil pengolahan dari tabung inhop diambil masing - masing $500 \mathrm{ml}$ (sampel). Kedua sampel di uji kualitas airnya dengan pengujian Fisika ( Bau, Warna, Turbidity (kekeruhan), Conductivity (DHL), Suhu, Total Disolvent to Solute (jumlah padatan terlarut) ) dan pengujian Kimia (pH, Sulfat, Ammonia, Nitrit, Besi, Dissolved Oxygen (Oksigen terlarut), Zat Organik, Mangan, Klorida, Hardness (Kesadahan) serta Bikarbonat. Bandingkan kedua sampel tersebut.

\section{Uji Fisika}

Diambil $50 \mathrm{ml}$ sampel untuk dilakukan analisa Bau dan warna menggunakan metode organoleptik atau visual. Lalu di lanjutkan untuk uji Turbidity (kekeruhan) menggunakan alat Turbiditimeter. Pengujian Conductivity (DHL) dan Total Disolvent to Solute (jumlah padatan terlarut) menggunakan alat Conductimeter dan Suhu menggunakan alat $\mathrm{pH}$ meter. 


\section{Uji Kimia}

Diambil $450 \mathrm{ml}$ sampel untuk dilakukan pengujian :

a. $\mathbf{p H}$

ambil $60 \mathrm{ml}$ sampel masukkan ke dalam Beaker glass $100 \mathrm{ml}$ kemudian masukkan elektrode $\mathrm{pH}$ meter kedalam air sampel untuk mengetahui nilai pH (keasaman).

b. Sulfat

Ambil $25 \mathrm{ml}$ air sampel masukkan ke dalam Erlenmeyer $100 \mathrm{ml}$ kemudian di beri larutan Konditioner Sulfat sebanyak 1,25 ml dan 1 sudip bubuk Barium Klorida. Diamkan selama 10 menit kemudian baca menggunakan Helige Tester.

\section{c. Ammonia}

Ambil $25 \mathrm{ml}$ air sampel masukkan ke dalam Erlenmeyer $100 \mathrm{ml}$ kemudian di beri larutan Pottasium Sodium Tartat sebanyak $0,13 \mathrm{ml}$ dan 0,25 ml larutan Nesler. Diamkan selama 10 menit kemudian baca menggunakan Helige Tester.

d. Nitrit

Ambil $25 \mathrm{ml}$ air sampel masukkan ke dalam Erlenmeyer $100 \mathrm{ml}$ kemudian di beri larutan Anafthanilamin sebanyak 0,5 ml dan 0,5 ml larutal Sulfanil Acid. Diamkan selama 10 menit kemudian baca menggunakan Helige Tester.

e. Besi

Ambil $25 \mathrm{ml}$ air sampel masukkan ke dalam Erlenmeyer $100 \mathrm{ml}$ kemudian di beri larutan Sulfanil acid sebanyak 1,25 ml dan 0,75 ml larutal Asam Sulfat 4 N. Diamkan selama 10 menit kemudian baca menggunakan Helige Tester.

\section{f. Dissolved Oxygen ( Oksigen terlarut )}

Ambil $125 \mathrm{ml}$ air sampel masukkan ke dalam Tabung asah $250 \mathrm{ml}$ kemudian di beri 0,5 ml larutan Mangan Sulfat di tambah 0,5 ml larutan alkalin dan 0,5 ml Asam Sulfat Pekat. Diamkan selama 10 menit kemudian baca menggunakan Helige Tester.

\section{g. Zat Organik}

Ambil $50 \mathrm{ml}$ air sampel masukkan ke dalam Erlenmeyer $250 \mathrm{ml}$ kemudian di beri larutan asam Sulfat $4 \mathrm{~N}$ sebanyak $5 \mathrm{ml}$, panaskan menggunakan hotplate sampai mendidih. Setelah mendidih tambahkan larutan $\mathrm{KMnO}_{4}$ 0,01 N 5 ml panaskan dengan suhu $40-700 \mathrm{C}$ selama 10 menit. Setelah itu di beri asam Oksalat $0,1 \mathrm{~N}$ sebanya $0,5 \mathrm{ml}$ dan amati perubahan yang terjadi. Jika larutan tetap berwarna ungu maka Nilai Zat Organik 0, jika larutan berubah menjadi bening maka sampel harus di titrasi menggunakan $\mathrm{KMnO}_{4} 0,1 \mathrm{~N}$ sampai berubah warna menjadi merah muda. Catat Volume Titrasi dan Hitung nilai zat Organik air Sampel.

$$
\text { ZatOrganik }(m g / l)=\left(\left(\frac{\text { volumetitrasi }}{10} x 0,952\right)-10\right) x 3,16
$$

\section{h. Mangan}

Ambil $50 \mathrm{ml}$ air sampel masukkan ke dalam Erlenmeyer $250 \mathrm{ml}$ kemudian di beri Asam Nitrat $6 \mathrm{~N}$ sebanyak $5 \mathrm{ml}$ dan Perak Nitrat $10 \%$ sebanyak 6 tetes, panaskan menggunakan hotplate sampai mendidih. Setelah mendidih tambahkan larutan bubuk titriplex 1 sudip. Amati perubahan warna sampel jika tetap bening maka Mangan 0, jika terbentuk warna merah muda berarti sampel mengandung Mangan dan di baca menggunaka Helige Tester.

\section{i. Klorida}

Ambil $50 \mathrm{ml}$ air sampel masukkan ke dalam Erlenmeyer $250 \mathrm{ml}$ kemudian di beri $\mathrm{K} 2 \mathrm{Cr} 2 \mathrm{O} 4$ 5\% sebanyak 7 tetes kemudian titrasi menggunakan Perak Nitrat 0,1 N sampai warna kuning kecoklatan. Catat volume titrasi dan Hitung nilai Klorida sampel. 


$$
\text { Klorida }(m g / l)=\text { VolumeTitrasix } 35,5
$$

\section{j. Hardness (Kesadahan)}

Ambil $50 \mathrm{ml}$ air sampel masukkan ke dalam Erlenmeyer $250 \mathrm{ml}$ kemudian di beri $2 \mathrm{ml}$ Buffer Hardness dan 1 sudip Indikator hardness. Titrasi dengan Larutan EDTA 0,1 N sampai warna ungu kebiruan. Catat volume titrasi dan Hitung nilai Kesadahan sampel.

$$
\operatorname{Hardness}(m g / l)=(\text { volumeTitrasix } 10) \times 17,8
$$

\section{k. Bikarbonat}

Ambil $50 \mathrm{ml}$ air sampel masukkan ke dalam Erlenmeyer $250 \mathrm{ml}$ kemudian di beri 3 tetes Methyl Orange. Titrasi menggunakan asam Klorida 0,1782 $\mathrm{N}$ hingga warna orange. Catat volume titrasi dan Hitung nilai Bikarbonat sampel.

$$
\text { Bikarbonat }(m g / l)=(\text { VolumeTitrasix } 61) x(N . H C l x 10)
$$

\section{Perhitungan Persentase residu Pengolahan Pasir kuarsa}

\section{Berat Residu}

Berat Residu $=($ Berat Pasir Awal $-(($ Berat Pasir Sisa + Berat kertas saring dan Residu $)-$ Berat Kertas Saring ))

Persentase Residu

$$
\text { Persentase (\%)Residu }=\frac{\text { Beratresidu }}{\text { Beratpasirawal }} \times 100
$$

\section{HASIL DAN PEMBAHASAN}

\section{Persentase (\%) Residu yang dihasilkan}

Tabel 1. Rekapitulasi Persentase Residu yang dihasilkan

\begin{tabular}{|c|c|c|c|c|c|c|}
\hline \multirow{2}{*}{ Waktu } & \multicolumn{5}{|c|}{$\%$ Residu } \\
\cline { 3 - 7 } & & $\begin{array}{c}\text { Konsentrasi } \\
\text { NaOH 2M }\end{array}$ & $\begin{array}{c}\text { Konsentrasi } \\
\text { NaOH 4M }\end{array}$ & $\begin{array}{c}\text { Konsentrasi } \\
\text { NaOH 6M }\end{array}$ & $\begin{array}{c}\text { Konsentrasi } \\
\text { NaOH 8M }\end{array}$ & $\begin{array}{c}\text { Konsentrasi } \\
\text { NaOH 10M }\end{array}$ \\
\hline 15 & 1,30 & 3,07 & 8,47 & 11,90 & 17,97 & 17,43 \\
\hline 20 & 2,18 & 4,17 & 10,07 & 9,60 & 19,80 & 16,63 \\
\hline 25 & 2,80 & 4,43 & 9,13 & 10,10 & 15,23 & 16,47 \\
\hline 30 & 3,20 & 4,87 & 12,47 & 9,70 & 15,20 & 15,13 \\
\hline
\end{tabular}

Sumber : Hasil Pengujian Laboratorium PDAM Tirta Musi Palembang

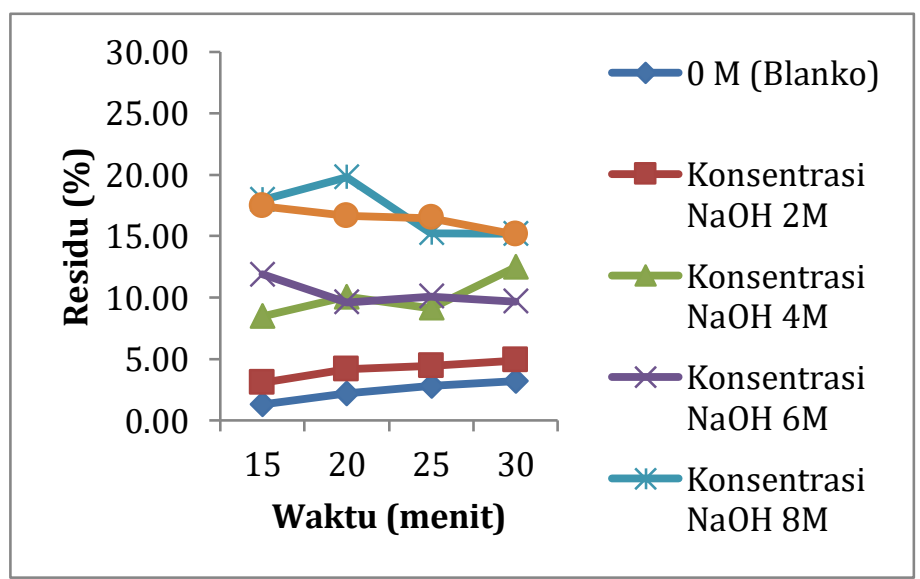

Gambar 1. Grafik hubungan Waktu vs Residu (\%) terhadap beberapa konsentrasi $\mathrm{NaOH}$ 
Hasil data pada Tabel 1. Menunjukkan bahwa Pada semakin tinggi konsentrasi maka persentase residu yang dihasilkan semakin menurun. Hal ini disebabkan oleh adanya pengaruh konsentrasi pelarut yang digunakan. Semakin tinggi konsentrasi pelarut yang digunakan membuat pelarut semakin jenuh sehingga dapat memperlambat proses reaksi. Dari data yang diproleh, konsentrasi dan waktu pelarutan yang optimal yaitu pada konsentrasi $\mathrm{NaOH} 8 \mathrm{M}$ selama 20 menit dengan persentase residu sebesar $19,80 \%$.

\section{Analisis Kecepatan Pengolahan Pasir Kuarsa}

Tabel 2. Analisa Kecepatan Pengolahan

\begin{tabular}{|c|c|c|c|}
\hline Jenis Pasir & Volume pasir $(\mathrm{mL})$ & Volume Air (mL) & Kecepatan (menit) \\
\hline \multicolumn{4}{|c|}{ Pasir yang Telah Diolah } \\
\hline Penyaringan 1 & 500 & 1000 & 2,54 \\
\hline Penyaringan 2 & 500 & 1000 & 2,31 \\
\hline Penyaringan 3 & 500 & 1000 & 2,06 \\
\hline \multicolumn{4}{|c|}{ Pasir Tanpa Pengolahan } \\
\hline Penyaringan 1 & 500 & 1000 & 14,11 \\
\hline Penyaringan 2 & 500 & 1000 & 13,56 \\
\hline Penyaringan 3 & 500 & 1000 & 13,48 \\
\hline
\end{tabular}

Dari hasil kecepatan penyaringan pasir filter terdapat perbedaan yang nyata, diketahui bahwa menggunakan pasir yang telah diolah (Pasir hasil analisa residu yang telah di keringkan), jauh lebih cepat dimana rata - rata waktu yang di butuhkan adalah 13,72 menit dengan kualitas warna air yang semakin jernih tiap kali dilakukan pengolahan ulang (3 kali pengulangan), karena residu yang terkandung tidak ikut terlarut lagi sehingga tingkat kekeruhan menurun. Sedangkan menggunakan pasir tanpa pengolahan (pasir langsung dari bak filter dan dikeringkan) dimana rata - rata waktu kecepatan yaitu 2,30 menit, disini terlihat bahwa pasir kotor membutuhkan waktu lebih lama dalam pengolahan karena banyak mengandung lumpur yang menutupi pori - pori pasir kuarsa tersebut dan kualitas air yang dihasilkan berwarna kecoklatan, hal ini sesuai dengan pendapat Perpamsi (2013) bahwa selama proses filtrasi, hambatan filter semakin meninggi disebabkan oleh zat padat yang tertahan didalam media pori - pori pasir Kuarsa.

\section{Perbandingan Hasil Uji Kualitas Air Sebelum dan Setelah Pengolahan}

Berdasarkan uji kualitas fisik dan kimia air filter dilakukan dua perlakuan yaitu pengolahan air menggunakan pasir yang telahdiolah (setelah pengolahan) dan air menggunakan pasir tanpa pengolahan (Sebelum pengolahan). Pada masing - masing perlakuakn terdapat perbedaan pada setiap pengujian. Pada pengujian sebelum penyaringan Turbidity yang di dapat yaitu 4,23 NTU sedangkan setelah penyaringan didapat Turbidity dengan nilai 1,10 NTU. Hal ini menunjukan aktivasi pasir menggunakan Chemical mampu memaksimalkan kinerja pasir sebesar 74\%.

Dari tabel 3 di dapat $\mathrm{pH}$ air sebelum pengolahan yaitu 5,95 setelah pengolahan $\mathrm{pH}$ yang di dapat 6,14, hal ini menunjukan penikatan $\mathrm{pH}$ dikarenakan aktivasi menggunakan $\mathrm{NaOH}$ yang bersifat basah.

Conductivity (Daya Hantar Listrik) air sebelum dan setelah diolah terjadi penurunan dari $54,1 \mathrm{us} / \mathrm{cm}$ ke 50,6 us/cm. Hal ini sesuai dengan pendapat effendi (2003:63) bahwa semakin banyak garam terlarut yang dapat terionisasi maka semakin tinggi nilai nilai daya hantar listrik.

Temperature (Suhu) biasanya di pengaruhi musim, pada pengamatan diketahui suhu $26^{\circ} \mathrm{C}$. Menurur effendi (2003 : 57), suhu suatu badan air dipengaruhi oleh musim, lintang, ketinggian dari permukaan laut, waktu dan hari, siklus udara, aliran serta kedalaman badan air. 
Tabel 3. Kualitas Air Sebelum dan Setelah Pengolahan

\begin{tabular}{|c|c|c|c|c|}
\hline Parameter & $\begin{array}{l}\text { Air Sebelum } \\
\text { Pengolahan }\end{array}$ & $\begin{array}{l}\text { Air Setelah } \\
\text { Pengolahan }\end{array}$ & $\begin{array}{c}\text { Maksimal nilai } \\
\text { yang di } \\
\text { perbolehkan } \\
\text { (permenkes } \\
\text { 409/2010) } \\
\end{array}$ & Satuan \\
\hline \multicolumn{5}{|l|}{ Uji Fisik } \\
\hline $\mathrm{Bau}$ & Tidak Berbau & Tidak Berbau & Tidak Berbau & - \\
\hline Warna & 3 & 1 & 15 & TCU \\
\hline Turbidity & 4,23 & 1,1 & 5 & NTU \\
\hline Conductivity & 54,1 & 50,6 & 1500 & $\mathrm{uS} / \mathrm{cm}$ \\
\hline Suhu & 27,9 & 27,6 & \pm 3 suhu udara & Deg C \\
\hline $\begin{array}{l}\text { TDS (Total } \\
\text { Dissolved Solute) }\end{array}$ & 27,6 & 25,3 & 500 & $\mathrm{mg} / \mathrm{l}$ \\
\hline \multicolumn{5}{|l|}{ Uji Kimia } \\
\hline $\mathrm{pH}$ & 5,95 & 6,14 & $6,5-8,5$ & - \\
\hline Sulfat & 48 & 34 & 250 & $\mathrm{mg} / \mathrm{l}$ \\
\hline Ammonia & 0,05 & 0,03 & 1,5 & $\mathrm{mg} / \mathrm{l}$ \\
\hline Nitrit & 0,003 & 0,003 & 3 & $\mathrm{mg} / \mathrm{l}$ \\
\hline Besi & 0,2 & 0,1 & 0,3 & $\mathrm{mg} / \mathrm{l}$ \\
\hline Zat Organik & 8,1 & 3,4 & 10 & $\mathrm{mg} / \mathrm{l}$ \\
\hline Mangan & 0 & 0 & 0,4 & $\mathrm{mg} / \mathrm{l}$ \\
\hline Klorida & 23 & 19 & 250 & $\mathrm{mg} / \mathrm{l}$ \\
\hline Kesadahan & 8 & 5 & 500 & $\mathrm{mg} / \mathrm{l}$ \\
\hline
\end{tabular}

TDS (Padatan terlarut) yang diperoleh dari data diatas menunjukan kondisi yang sangat bagus karena jauh dari nilai ambang yang diperbolehkan. TDS biasanya disebabkan oleh bahan - bahan anorganik yang ditemukan di perairan. Ion - ion anorganic yang biasanya terdapat di peraiaran antara lain Calsium (Ca), Sodium (Na), Magnesium (Mg), Bicarbonat (HCO3), Sulfat (SO4), Klorida (Cl), dll. Transparansi dan warna air dipengaruhi oleh TDS. Padatan terlarut mengandung kepekatan padatan dalam suatu sampel air. Menurut Sutrisno (1991 : 33) di dalam air banyak mengandung garam anorganik dan gas terlarut. TDS sangat berkaitan erat dengan Turbidity (Kekeruhan), jika TDS tinggi maka tingkat kekeruhan juga akan tinggi.

\section{KESIMPULAN}

Dari hasil penelitian dan anlisa terhadap pengaruh konsentrasi dan waktu terhadap persentase (\%) residu yang dihasilkan, dapat disimpulkan bahwa :

1. Konsentrasi pelarut yang optimal untuk aktivasi pasir kuarsa sebagai media filter di PDAM Tirta Musi Palembang IPA Rambutan adalah menggunakan NaOH 8M selama 20 menit.

2. Waktu rata - rata pengolahan air untuk pasir yang telah di aktivasi adalah 2,30 menit sedangkan menggunakan pasir kuarsa tanpa di aktivasi, membutuhkan waktu selama 13,72 menit.

3. Tahapan Washing yang tepat untuk pasir kuarsa sebagai media filter di PDAM Tirta Musi di IPA Rambutan yakni melakukan Backwash, kemudian mereaksikan pasir kuarsa menggunakan HCL 2M selama 5 - 10 menit lalu di bilas dengan air kemudian dilanjutkan meng-aktivasi pasir kuarsa menggunakan $\mathrm{NaOH}$ 8M selama 20 menit, setelah itu lakukan Backwash kembali.

\section{SARAN}

Pada Kesempatan ini, Penulis juga memberikan saran yang berkaitan dengan penelitian, yaitu : 
1. Pentingnya aktivasi terhadap pasir kuarsa di PDAM Rambutan IPA Rambutan minimal selama 2 (dua) tahun sekali.

2. Dengan melakukan aktivasi dengan chemical dapat mempersingkat waktu pengolahan air.

3. $\mathrm{HCl}$ dan $\mathrm{NaOH}$ dapat dijadikan sebagai solusi alternatif untuk mengaktifasi kembali pasir kuarsa selain mengganti pasir kuarsa.

\section{DAFTAR PUSTAKA}

Asmuni. Drs. 2008. Karakteristik Pasir Kuarsa (SiO2) dengan Metode XRD. FMIPA USU. Sumatera Selatan.

Buchan, James.2003. Crowded with genius: the Scottish enlightenment: Edinburgh's moment of the mind. New York: Harper Collins. Christman, Keith. (1998). The history of chlorine. Waterworld, 14 (8), 66-67.Concepts and Practice of Humanitarian Medicine. An Act to make better Provision respecting the Supply of Water to the Metropolis, (15 \& 16 Vict. C.84).

Effendi, H.2003. Telaah Kualitas Air. Kanisius. Yogyakarta : 257 hlm.

Hadi, Surahmat, dkk. 2011. Sintesis Silika Berbasis Alam Bancar Menggunakan Metode Kopresipitasi. Fakultan Matematika dan Ilmu Pengetahuan Alam Universitas Sepuluh Nopember, Surabaya.

Johnson, Georg.2007. Present day water filtration practice. American Water Works Association. 1 (1): 31. Retrieved 18 May 2017. "History | Poughkeepsies' Water Treatment Facility". pokwater.com. Poughkeepsies' Water Treatment Facility. Retrieved 18 May 2017.Centre for Affordable Water and Sanitation Technology, Biosand Filter Manual: Design, Construction, \& Installation," July 2007.

Perpamsi (Persatuan Perusahaan Air Minum Seluruh Indonesia). 2003. Pedoman Pelatihan Bagi Petugas Laboratorium Instalasi Pengolahan Air). Majalah Air Minum. Kerjasama Pemerintah - Jerman Proyek pengawasan Kalitas Air Direktorat Penyehatan Air Minum dan Sanitasi Departement Kesehatan Publik Indonesia.

Qasemy, Nawid.2015.Rapid Sand Filtration. Authorstream.com. nawid11. Retrieved 01 April 2018.

Quddus, Rachmat.2014. Pengolahan Air Bersih dengan Sistem Saringan Pasir Lambat (Downflow) yang bersumber dari sungai Musi. Fakultas Teknik Universitas Sriwijaya, Palembang

Sastrawijaya, T. 2000. Pence, aran Lingkungan. Penerbit Rineka Cipta. Jakarta : viii +274 hlm.

Sugiharto.1987. Dasar Pengolahan Air Limbah. Penerbit Universitas Indonesia. Jakarta: viii +798 hlm.

Sunarno.Drs. 2002. Pengaruh pertumbuhan Algae Terhadap Unit Operasi dan Unit Proses Instalasi Penjernihan Air.

Sutrisno, T.1991. Teknik Penyediaan Air Bersih. PT. Rineka Cipta. Jakarta: viii+ 293 hlm 
United States Environmental Protection Agency (EPA).1990. Technologies for Upgrading Existing or Designing New Drinking Water Treatment Facilities (Report). Cincinnati, OH. EPA 625/4$89 / 023$.

Windusari, Yuanita, dkk. 2015. Kualitas perairan sungai Musi di Kota Palembang Sumatera Selatan.

Fakultan Matematika dan Ilmu Pengetahuan Alam Universitas Sriwijaya dan Anggota Internasional Association of Lowland and Technology, Sumatera Selatan. 